Review: Experimentation in Phytogeography

Source: Journal of Ecology, Vol. 1, No. 2 (Jun., 1913), p. 123

Published by: British Ecological Society

Stable URL: http://www.jstor.org/stable/2255679

Accessed: 26-03-2016 21:30 UTC

Your use of the JSTOR archive indicates your acceptance of the Terms \& Conditions of Use, available at

http://about.jstor.org/terms

JSTOR is a not-for-profit service that helps scholars, researchers, and students discover, use, and build upon a wide range of content in a trusted digital archive. We use information technology and tools to increase productivity and facilitate new forms of scholarship. For more information about JSTOR, please contact support@jstor.org.

Wiley, British Ecological Society are collaborating with JSTOR to digitize, preserve and extend access to Journal of Ecology

http://www.jstor.org 
an angle of $40^{\circ}$ to $90^{\circ}$ from the vertical, and force away all the surrounding herbs and grasses, except the adjoining Juncus rosettes. When seen in large numbers, the adjoining rosettes were all of about $10 \mathrm{~cm}$. diameter with an equal distance from centre to centre, hence in dense colonies of $J$. squarrosus little space is left for other herbaceous plants. Among the plants caught and suppressed between the Juncus rosettes on Crossfell are Agrostis vulgaris, Deschampsia flexuosa, Festuca ovina, Galium saxatile, Vaccinium Myrtillus, various mosses, Cladonia rangiferina, etc.; on Ben Lawers even the predominant firm and rigid Alchemilla alpina was shut up and flattened where the Juncus rosettes occurred densely. In Sphagnum, however, Juncus squarrosus succumbs; where these plants occurred together, on Crossfell, the Juncus was sunk deeply in the wet Sphagnum bed, and this grew freely over the leaf points of the rosettes, hence the Sphagnum was able to shut up the rosettes, the spreading Juncus leaves being unable to force back the moss.

\section{EXPERIMENTATION IN PHYTOGEOGRAPHY}

Massart, J. "Le rôle de l'expérimentation en géographie botanique." Rec. Inst. bot. Leo Errera, 9, 1912, pp. 68-80, 8 plates.

The author indicates various biological and ecological problems which he regards as being ripe for solution by experimental methods. For instance, detailed chemical, physical, physiological, and bacteriological studies of soils in various habitats have thrown much light upon some problems in plant distribution; in this connexion, the question of toxic root-excretions is one demanding thorough investigation.

If it be true that a given station can only be colonised by species which are structurally and physiologically in strict harmony with local conditions, it seems remarkable that certain species occur in stations so widely different that each of them would appear to be uninhabitable for the plants growing in the others (Koeleria cristata, Veronica hederaefolia, Polygonum amphibium, etc.). Is it in reality a single species that inhabits such diverse situations? In some cases the answer is easy, but more often observation is insufficient and experiment is necessary. The author proposes that the term "accommodation" should be reserved for the transformation undergone by the individual when it places itself in harmony with its environment, and "adaptation" for that undergone by the species under the action of variability and natural selection. Adaptation is hereditary, accommodation is not.

Experimental studies on the origin of species by mutation and by hybridisation have demonstrated conclusively that a species has not necessarily a single origin, and that hybridisation may give rise to fertile and stable species. The author urges that in investigations of this kind, relating to wild plants, the habitat should be taken into account, and that there should be co-operation between the ecologist, the plant physiologist, the chemist, and the worker on variation and evolution, since the work of each throws light on the facts observed by the others.

\section{CAUSE OF THORN DEVELOPMENT}

Lothelier, A. " "De l'influence de l'humidité de l'air sur le développement des épines de l'Ulex europaeus." Rev. gén. de Bot., 24, 1912, pp. 296-297.

Since the earlier work of Lothelier (1893) on the experimental morphology of thorns, it has been generally believed that the development of these structures is favoured, and even caused, by atmospheric desiccation or by intense illumination, or both factors acting together. Lothelier found that in Ulex europaeus the branches of the second order, which normally end in a sharp spine, grew out to form leafy shoots when caused to develope in humid air or in feeble light; he obtained similar results with Berberis, Crataegus, etc. Cockayne (New Phytologist, 4, 1905, p. 79) found that in Discaria toumatou, a New Zealand rhamnaceous plant, spines are not developed in moist air and feeble light, their place being taken by leafy shoots of unlimited growth; hence he supported Lothelier's view.

Zeidler (Flora, 102, 1911, pp. 87-95) found that thorns were developed in Ulex plants kept 